https://doi.org/10.24101/logos.2017.78

Gauta 20171110

\title{
ANTANAS ANDRIJAUSKAS
}

Lietuvos kultūros tyrimų institutas

Lithuanian Culture Research Institute

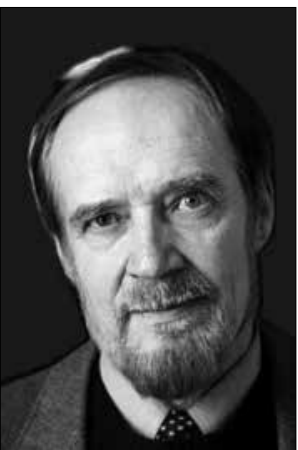

\section{METAFIZINĖS GELMĖS IEŠKOJIMAS ANTANO SAVICKIO (TONIO VIBERIO) TAPYBINÉSE MEDITACIJOSE}

\author{
The Search for Metaphysical Depth \\ in Antanas Savicki's (Tony Viber's) \\ Pictorial Meditations
}

\begin{abstract}
SUMMARY
The article is dedicated to the analysis of a specific creative style of Antanas Savickis (Tony Viber), a younger generation painter. It briefly discusses his creative sources, essential evolutionary turns, experienced influences, contacts with various movements of modern and post-modern art. His paintings are full of creative bursts, expression, spiritual clarification, sadness, woeful anxiety, and other most intimate moods which spread out through sensitive colour shades, and complex interactions between forms, rhythms, lines and factures. Abstract form, quirky line, and emotional colour thus become the fundamental elements of the painter's plastic language, helping to extract the effects of musicality and harmony from the painting space. The article presents Savickis' most important works and discusses the means of their artistic expression.
\end{abstract}

\section{SANTRAUKA}

Straipsnis skirtas jaunesniosios kartos tapytojo Antano Savickio (Tonio Viberio) kūrybinio stiliaus savitumo analizei. Jame glaustai aptariamos dailininko kūrybos ištakos, pagrindiniai kūrybinès evoliucijos vingiai, patirtos įtakos, sąlyčiai su įvairiomis modernistinio ir postmodernistinio meno kryptimis. Dailininko tapyba kupina gaivališkų kūrybos proveržių, ekspresyvumo, dvasios nuskaidrẻjimo, liūdesio, slogaus nerimo ir kitų intymiausių nuotaikų, kurios skleidžiasi per jautriausius koloritinius atspalvius, sudètingus formų, ritmų, linijų ir faktūru santykius. Abstrakti forma, vingri linija ir emocionali spalva tampa pagrindiniais tapytojo plastinès kalbos elementais, padedančiais tapomoje erdvèje išgauti muzikalumo ir harmonijos efektus. Straipsnyje pristatomi svarbiausi dailininko kūriniai, aptariamos jų meninės išraiškos priemonès. 


\section{A} ntanas Savickis (g. 1984 m.) yra savitas jaunosios kartos savo kūrybą reflektuojantis Lietuvos intelektualiosios tapybos atstovas. Tai postmoderniam metacivilizacinès kultūros pasauliui būdingas kosmopolitinio menininko tipas, kuriam kultūrinès aplinkos keitimas, „buvimas kelyje“ yra natūrali autentiškos būties stichija - kelionèse galima semtis naujų turtingų emocinių išgyvenimų ir kūrybinių impulsų. Šio jauno iš Lietuvos kilusio dailininko gyvenimo ir kūrybos kelyje gimtuosius Šiaulius periodiškai keičia Maskva, Londonas, Nikosija, o šiandien - Dubajus. Jam, kaip ir daugeliui menininku intravertu, išpažistančiu individualistinès pasaulejjautos principus, būdingas nepasitenkinimas esama tikrove, noras paneigti vyraujančias dabartinio totaliai komercializuoto pasaulio vertybines ir estetines nuostatas, plèsti savo autentiškos kūrybinès raiškos erdves.

Kita vertus, šio ambicingo dailininko kūryba glaudžiai siejasi su savitu filosofiniu požiūriu i pasaulį ir blykstelèjimais gaivališkos kūrybinès energijos, kuri išsilieja spalvinguose galingos ekspresijos kupinuose spalvinguose tapybos kūriniuose. Neabejotiną poveiki Savickio tapybos raidai turejjo hermeneutinès filosofijos studijos Maskvos Lomonosovo v. universiteto doktorantūroje, kurios padejo suvokti tapyboje atsiveriančias neišsemiamas vaizduotès kuriamos meninès tikrovès interpretacijos galimybes. Tai lèmé ypatingą dèmesį tapybos teikiamoms abstrakčios ir spontaniškos meninès saviraiškos galimybėms. Savickis savo neramia prigimtimi, įvairių išorinių reglamentacijos formų nepaisymu, pani- rimu i ǐios būties akimirkos išgyvenimus artimas introvertiškos pakraipos intelektualiems dailininkams, klajojantiems svaju pasaulio bekraštybėse ir linkstantiems spręsti problemas plastine tapyba. Esu intravertas, - prisipažista jis, - visada noréjau pakeisti ši pasauli, padaryti ji geresne vieta žmogaus gyvenimui; pradžioje tikejausi tai padaryti pasinerdamas i filosofines hermeneutikos studijas, tačiau ilgainiui filosofija man pasirode esanti pernelyg dogmatiška, ispausta i griežtus rèmus ir taisykles. Trokštama saviraiškai sriti galiausiai radau tapyboje, kuri suteike galimybe laisviau reikštis mintims, jausmams, nereikalavo tikslumo, užteko spalvu ir formu jausmo, atverusio naujas idejju raiškos galimybes." ${ }^{1}$

Svarbiausia Savickiui - ne išorinis, o vidinio dramatizmo atspalviais pažymètas metaforiškas tikrovès suvokimas. Iš čia kyla dailininko drobėms būdingas ypatingas dèmesys ne tik pasaulinès kultūros istorijai, bet ir grynai plastiniam meno kūrinio aspektui - ekspresijai, sudètingiems kompoziciniams sprendimams, spalvai, koloritui, spontaniškai tapymo manierai, muzikalių linijinių ritmų sąveikai ir ívairiems emocionaliems spalvu atspalviams. Jam artimas egzistencinès pakraipos prancūzų meno filosofijos korifejjaus André Malraux požiūris ị principini šiuolaikinio meno autonomiškumą tikrovės atžvilgiu ir programinis jo teiginys, kad mena kuria gyvenimas, tačiau menu tampa tik tuomet, kai išslysta iš jo ittakos. Todèl realizmo terminas Malraux meno filosofijoje igauna neigiamą prasmę ir yra "neautentiškos" kūrybos sinonimas. Tikras menininkas tikrovès oponentas, varžovas, kuris savo kūriniuose tikra pasauli keičia aukštesne 
autonomiška menine tikrove. Menininkas vaizduoja ne tai, „,kas yra tikroveje, o tai, ką nori matyti, ką verta vaizduoti“ ${ }^{\text {“2 }}$.

Analogiškomis nuostatomis savo kūrybiniame kelyje vadovaujasi Savickis. Aptariant jo tapybos ištakas, iš pasąmonès gelmiu pirmiausia išnyra fovizmo, lyrinės abstrakcijos, abstraktaus ekspresionizmo, tašizmo, gesto tapybos ir netgi grafičiu tapybos technikos apraiškos. Tarp jo ikkvejpejju galima beveik tiesai vardanti šiuos modernistinès ir postmodernistinès dailès korifejus: Henri Matisse'as, Jeanas Dubuffet, Georgesas Mathieu, Jacksonas Pollackas, Markas Rothko, Willemas de Kooningas, Cy Twombly, Archilas Gorky, Franzas Kline'as, Jean-Michelis Basquiat. Ekspresyvi prigimtis ir spontaniški kūrybinès dvasios polèkiai dailininką skatina atsiriboti nuo jau išsėmusios savo galimybes realistinès ir natūralistinès tapybos estetikos, o spalva ir muzikalios formos natūraliai vaduojasi iš siužetinès priklausomybès ir pirmiausia skleidžiasi ekspresionistinio ir abstraktaus meno tendencijų nubrēžtose erdvese.

Savito stiliaus tapsmo ir naujų meninès raiškos formų įsitvirtinimo požiūriu labai svarbūs yra 2012-2013 m., kai sukuriami įvairūs Dubuffet, De Kooningo, Cy Twombly, Basquiat stilių kūriniai. Žvelgiant i geriausius šiuo tarpsniu sukurtus įvairių stiliu, skirtingų plastinių, spalviniu, koloritiniu ir kompoziciniu sprendimu paveikslus "The End of World“ (2012), „Sexuality“ (2013), „Tonque shover" (2013), "Dirthy woman" (2013) gali pasirodyti, kad tai sukurta skirtingu menininku arba bent skirtingais to paties tapytojo kūrybinès evoliu- cijos laikotarpiais. Apibūdinti pagrindines šiuose kūriniuose išryškëjusias Savickio tapybos tendencijas galime pasitelkdami garsaus meno kritiko Waldemaro George'o žodžius, pasakytus apie abstrakčius A. Galdiko paveikslus. Kalbėdamas apie šio mūsų klasiko tapiniu savituma jis pabrèžia sąsajas su muzikine raiška, kad tapytojas tarsi muzikas it kompozicijas ivveda ivairių temos variantu, tačiau visuomet išsaugo harmoningos linijos tęstinumą. Jo linijinè struktūra pranyksta. Spalva pamažu tampa vieninteliu konstruktyviu elementu. Ji žaidžia formomis, lyg ji viena tebūtu tikrovè. Ji jas įtraukia i save ir pakeičia" ${ }^{3}$.

Kita vertus, šie su savito kelio ieškojimu susiję eksperimentai, žavintys plačia netikètu spalvinių ir kompoziciniu sprendimu gama nuo niūrių iki šviesių nuotaikingu spalvu rodo akivaizdų Savickio plastinès kultūros augima, dailininko atsiribojimą nuo vyraujančios tradicinės grožio sampratos. Manau, XXI a. mene grožio samprata tampa labai reliatyvi, - aiškina savo estetine pozicija dailininkas, - svarbi čia jau ne tik išraiškos forma, o galimybe emocionaliai paveikti žiūrova, kas šiais vizualinés informacinio pertekliaus laikais darosi vis sudètingiau 4 .

Sugèręs i save įvairias modernistinio ir postmodernistinio meno tendencijas, Savickis, be kitu darbu, pastaruosius penkerius metus itin daug dèmesio skyrè pagrindinio savo ciklo "Sielos" kūrimui. Jis nutape apie pusšimti šio ciklo paveikslų, kuriems būdingi abstrakčios tapybos motyvai, tačiau jie skiriasi spalviniu sprendimu ívairove, tad tampa tarsi paties kūrèjo „vidinès dvasios būsenos" raiškomis. Šios drobès stiliumi 
artimiausios lyrinės abstrakcijos tapybos tradicijai. Intymiausiuose šio ciklo paveiksluose tarsi sustabdoma laiko tèkmė; čia atsiranda muzikinio komponavimo principams būdingas laikinis mąstymas, ritminès struktūros, ritmo sulètėjimai, kurie aktyviai sąveikauja su erdvinemis paveikslo struktūromis, ekspresyvių dinamiškų vingrių liniju energetika.

Tapytojas daugiausia dèmesio skiria nesiužetiniams plastiniams arba, kitais žodžiais tariant, formaliems tapybos aspektams ir puikiai suvokia didaus prancūzų meno filosofo A. Malraux teiginio, kad „menas pirmiausia yra formų kalba” tikrają prasmę. Tai lemia Savickio kūrybai būdingą pasinèrimą i grynai estetiniu, kupinu muzikalios architektonikos plastinių tapybos struktūrų pasauli. Dailininkas supranta, kad abstrakti forma savaime yra vidinés prasmés išraiška, todèl tapydamas abstrakčias ir pusiau abstrakčias metaforiškas ir simbolines formas, pirmiausia išryškina ju kompozicinę sąveiką ir vidinį ryši su muzikaliu spalviniu ir koloritiniu kuriamos vaizdiniu sistemos sprendimu.

\section{Literatūra ir nuorodos}

1 A. Savickio laiškai A. Andrijauskui. Asmeninis archyvas.

2 Malraux André, La création artistique. Paris, 1948, p. 156.
Dailininko tapiniai kupini ekstatiniu kūrybos proveržiu, ekspresyvumo, dvasios nuskaidrèjimo, liūdesio, slogaus nerimo ir kitu intymiausių nuotaikų, kurios skleidžiasi per jautriausius koloritinius atspalvius, sudètingus formu, ritmų, linijų ir faktūru santykius. Jo tapyba neatsiejama nuo asmeninès patirties, susidūrimo su žmogu supančiais daiktais, reiškiniais, kultūros ir meno kūriniu pasauliu, sukeliančiu jautriausius išgyvenimus ir sunkiai žodžiais nusakomą nuotaikų kaitą. Abstrakti forma, vingri linija ir emocionali spalva čia tampa pagrindiniais tapytojo plastinès kalbos elementais, padedančiais tapomoje erdvèje išgauti muzikalumo ir harmonijos efektus. Išorinis Savickio paveikslų mįslingumas iš pradžiu glumina, kadangi po užšifruota metafizinès simbolikos kupina forma, siužetinių simuliacijų atsisakymo skraiste slypi intensyvus mąstančio ir ieškančio dailininko meninis kūrybos procesas. Tai lemia meditacinį Savickio tapiniu pobūdi, kuris reikalauja, kad šis paveikslus kontempliuojantis suvokejas susitelktų $i$ vaizduojamųjų reiškinių esmę.

3 Waldemar-George. Adomas Galdikas, Charlotte Willard, Adomas Galdikas: A Color Odyssey. New York: October House, 1973, p. 165.

${ }^{4}$ A. Savickio laiškai A. Andrijauskui. Asmeninis archyvas. 